\title{
IL-I $\alpha$ correlates with severity of hepatitis C virus-related liver diseases
}

This article was published in the following Dove Press journal: Journal of Inflammation Research

\author{
Ahmed Khaled Tawfik' \\ Ahmed Mustafa Amin ${ }^{2}$ \\ Mohamed Yousef' \\ Noha Mohamed El-sayd' \\ Heba Elashry' \\ Mahmoud Elkadeem' \\ Sherief Abd-Elsalam' \\ 'Department of Tropical Medicine \\ and Infectious Diseases, Faculty of \\ Medicine, Tanta University, Tanta, \\ Egypt; ${ }^{2}$ Department of Microbiology \\ and Immunology, Faculty of Medicine, \\ Tanta University, Tanta, Egypt
}

Background and aims: Immunoregulatory cytokines influence the persistence of hepatitis $\mathrm{C}$ virus (HCV) chronic infection and the extent of liver damage. Interleukin-1 (IL-1) plays an important role in the inflammatory process. Some studies have demonstrated that IL-1 $\alpha$ production was impaired in patients with chronic infections of HCV, implying that IL- $1 \alpha$ may play a role in viral clearance. The aim of this study was to evaluate the serum level of proinflammatory cytokine IL- $1 \alpha$ in patients with chronic hepatitis $\mathrm{C}$ (CHC).

Methods: This study was performed on $20 \mathrm{CHC}$ patients with cirrhosis in (Group I), $20 \mathrm{CHC}$ patients without cirrhosis in (Group II), 20 hepatocellular carcinoma (HCC) patients with positive anti-HCV in (Group III), and 10 healthy subjects as a control group. Serum levels of IL-1 $\alpha$ were measured by enzyme-linked immunoassay technique.

Results: IL- $1 \alpha$ had the highest mean concentration in the HCC group and then in the group of $\mathrm{CHC}$ with cirrhosis compared to the group of $\mathrm{CHC}$ without cirrhosis. Also, it was higher in all studied groups than in the control group $(P<0.001)$. Statistical analysis showed that IL- $1 \alpha$ was positively correlated with bilirubin $(P \leq 0.001)$, alanine aminotransferase $(P=0.006)$, aspartate aminotransferase $(P=0.001)$, and viral load $(P=0.001)$ but it was negatively correlated with albumin $(P \leq 0.001)$ and $\mathrm{Hb}(P \leq 0.001)$, and was not significantly correlated with other parameters (age, international normalized ratio, urea, creatinine, white blood cells, and platelet count).

Conclusion: Serum level of IL- $1 \alpha$ was elevated in patients with $\mathrm{CHC}$ and its related liver diseases (liver cirrhosis and HCC) and can be used as an important parameter of inflammatory activity and for fibrosis evaluation in patients with chronic liver disease.

Keywords: HCV, interleukin- $1 \alpha$, cirrhosis, hepatocellular carcinoma, fibrosis

\section{Introduction}

Hepatitis $\mathrm{C}$ virus (HCV) infection is one of the most prevalent chronic infectious diseases throughout the world. Approximately 170 million people are chronically infected. Chronic HCV infection is one of the major causes of liver cirrhosis, and hepatocellular carcinoma (HCC). The rate of spontaneous recovery from acute HCV is about $15 \%-50 \%$, occurring within 3 months. This recovery is characterized by symptom improvement, normalized liver function tests, disappearance of HCV-RNA from serum, and appearance of $\mathrm{HCV}$ antibody. ${ }^{1-3}$

In Egypt, $\mathrm{HCV}$ is considered the major cause of chronic hepatitis, liver cirrhosis, and HCC. The prevalence of HCV is estimated to be $14.7 \%$. HCV genotype 4 is the most prevalent genotype accounting about $90 \%$ among Egyptian patients with chronic HCV infection. ${ }^{4-9}$
Correspondence: Sherief Abd-Elsalam Tropical Medicine Department, Faculty of Medicine, Tanta University, El Geish Street, Tanta, Gharbia Governorate, Egypt

Tel +201095159522

Email Sherif_tropical@yahoo.com 
Liver fibrosis occurs in most types of chronic liver diseases. It results from both liver cell damage and deposition of extracellular matrix protein..$^{10}$ Liver cirrhosis is a chronic progressive disease affecting the entire organ. It consists of nodular regeneration of liver parenchyma, deposition of fibrous septa, and, in addition, loss of hepatic architecture. ${ }^{11}$ Cirrhosis can be considered as an end-stage disease that may lead to death unless liver transplantation is done. The only preventive measures in cirrhotic patients are screening for esophageal varices and HCC. ${ }^{12}$

HCC is the fifth most common cancer throughout the world. It causes approximately 500,000 deaths annually. ${ }^{13}$ $\mathrm{HCC}$ is the second most common cancer in Egyptian men and the sixth most common one in Egyptian women. ${ }^{14,15}$ The incidence of $\mathrm{HCC}$ increases in proportion to the age, reaching its peak in patients over the age of $75 . .^{13}$

The immune response is a key component in the activation and maintenance of antiviral immunity. Defects in the host's immune response can lead to viral persistence. ${ }^{16}$ Patients with viral replication have weak HCV antigen-specific T-cell responses. However, strong responses may associate with a more benign course of disease. ${ }^{17}$ Immune response also includes induction of cytokines and initiation of the adaptive immune response. Early, specific, and sustained CD4+ and CD8+ responses directed against different HCV epitopes have been found to be associated with clearance of chronic HCV. ${ }^{18}$

Cytokines are low-molecular weight mediators of cellular communication. They are secreted by multiple cell types in the liver, particularly Kupffer cells. Proinflammatory cytokines such as interleukin-1 (IL-1), TNF, and IL-8 are known to be acute-phase cytokines. They play a role in the liver injury of acute and chronic liver diseases. ${ }^{19}$ Th1 cytokines correlate positively with liver inflammation in HCV infection. ${ }^{20}$ Functional impairment, suppression, or deletion of antigen-specific T-cells appears to be the most important determinant factor behind the progression to chronic liver disease. $^{21}$

IL-1 is one of the most prominent proinflammatory cytokines..$^{22}$ It has a key role in viral clearance and the host immune response. IL-1 has 2 isoforms, IL- $1 \alpha$ and IL- $1 \beta$. Both have similar biological functions. IL-1 can exert numerous biological effects on multiple cell types. ${ }^{23}$ Changes in IL-1 expression in HCV-infected patients have been well documented. Some studies suggested that patients with HCV had increased levels of serum IL-1. ${ }^{24}$ The biological roles of IL-1 in HCV infection cannot be denied. It can help viral clearance by regulating immune response, particularly antigen presentation. In addition, it can enhance interferonstimulated target gene expression, which has a role in antiviral activity. ${ }^{25}$

As regard to IL1 $\alpha$ and IL $1 \beta$, inactive IL $1 \beta$ precursor is cleaved by caspase- 1 into an active cytokine. However, IL1 $\alpha$ precursor is cleaved into a mature form and $\mathrm{N}$-terminal propiece by calpain. IL1 $\alpha$ can also be expressed on the cell membrane, possibly via a mannose-like receptor. ${ }^{26,27}$ Studies have suggested that membrane IL1 $\alpha$ is immunostimulatory and can promote antitumor immune responses including HCC through activation of T- and natural killer cells. ${ }^{28}$

Some studies have shown that IL- $1 \beta$ production might be impaired in chronic hepatitis $\mathrm{C}(\mathrm{CHC})$ from both peripheral blood and sinusoidal cells due to viral infection of monocytes/ macrophages..$^{23}$ However, $\mathrm{CHC}$ is found to be accompanied by augmented expression of other cytokines such as TNF- $\alpha$, IL-1 $\alpha$, and IL-2 in groups of children and of adult patients. IL-1 could here possibly find its application, which is the subject of further research. ${ }^{29}$ This study aimed to evaluate the serum level of proinflammatory cytokine IL-1 $\alpha$ in patients with $\mathrm{CHC}$.

\section{Methods}

This study was performed on $60 \mathrm{CHC}$ patients and 10 healthy subjects as a control group at the Department of Tropical Medicine, Tanta University Hospital, during the period from October 2015 to October 2016.

The subjects in this study were classified into 4 groups: Group I included 20 patients with $\mathrm{CHC}$ with cirrhosis; Group II included 20 patients with $\mathrm{CHC}$ without cirrhosis; Group III included 20 patients with CHC with HCC; Group IV: included 10 healthy persons as control group.

Written informed consent was obtained from all participants in the research. All participants' names were hidden and were replaced by code numbers to maintain privacy. Institutional ethical committee approval was obtained before the start of the study. The study protocol conforms to the ethical guidelines of the 1975 Declaration of Helsinki as reflected in a prior approval by the Tanta University Faculty of Medicine Research Ethical Committee.

Patients with $\mathrm{CHC}$ who were consistently positive for anti-HCV antibodies (Matrix-ELISA; third-generation assay) with detectable HCV-RNA by real-time PCR for at least 6 months were included in the study. HCV-RNA quantitation was done by real-time PCR using Cobas Ampli Prep/Cobas TaqMan HCV-RNA assay (Roche Diagnostics; Pleasanton, CA, USA) with a threshold of detection of 15 
IU/mL. Patients with liver disease caused by NAFLD/NASH, patients with cardiac cirrhosis or primary biliary cirrhosis or hereditary conditions of the liver, patients with acute hepatitis, patients with evidence of acute or chronic inflammatory syndrome of other origin, or patients with immunodeficiency states were excluded from the study.

All patients included in the study were subjected to full history taking, complete clinical examination, routine laboratory investigations including total and direct serum bilirubin, serum ALT and AST, serum albumin, prothrombin time, INR, complete blood picture, serum urea and creatinine level, HCV-Ab by enzyme-linked immunosorbent assay (ELISA), and specific laboratory investigation as measurement of serum levels of cytokine IL- $1 \alpha$ ELISA. These tests were performed in the clinical pathology laboratory in Tanta University Hospital.

Six mL venous blood samples were collected under aseptic conditions and subdivided in to 3 tubes. Two $\mathrm{mL}$ in EDTA tube for complete blood count, $2 \mathrm{~mL}$ in citrate tube for prothrombin time, and $2 \mathrm{~mL}$ in a plain tube for liver functions and ELISA technique. The samples were centrifuged to separate serum and were kept in sterile containers in the fridge at $-20^{\circ} \mathrm{C}$ till the assay was done.

Measurement of IL- $1 \alpha$ was done by quantitative sandwich enzyme immunoassay technique. The Assay Max Human Interleukin- $1 \alpha$ ELISA kit (Abcam, Cambridge, UK) was designed for detection of human IL- $1 \alpha$ in plasma, serum, and cell culture samples. This assay employs a quantitative sandwich enzyme immunoassay technique which measures IL- $1 \alpha$ in $>5$ hours.

Radiological investigation was performed for all patients enrolled in the study. Abdominal ultrasonography was performed on all patients to detect the liver cirrhosis and had a tumor detection limit of $1 \mathrm{~cm}$. Small HCC $(3 \mathrm{~cm})$ appeared hypoechogenic in most cases relative to the surrounding nontumorous liver. ${ }^{30}$

Triphasic spiral computed tomography, abdominal and pelvic, was performed for patients with HCC. During the arterial phase, tumors appear enhanced against the relatively unenhanced liver parenchyma. HCC is characterized by arterial hypervascularization followed by a rapid wash out, appearing hypovascular in the portal phase. ${ }^{31}$

\section{Statistical analysis}

All patient data were tabulated and processed using SPSS 19.0 (V.19 SPSS Inc, Chicago, IL, USA). Quantitative data are presented by mean $(X) \pm \mathrm{SD}$. Tests of normality were done for all groups to detect that data was normally distributed. Statistical methods used in this study were analysis of variance and Tukey's test. Fisher's exact test was performed for qualitative data. Pearson correlation test was done between serum IL- $1 \alpha$ and other parameters. In all tests, the level of significance was $P<0.05$.

\section{Results}

Group I included 20 patients with chronic HCV with liver cirrhosis; their age ranged from 38 to 65 years. Twenty patients with chronic HCV without cirrhosis were enrolled in Group II, and they were aged between 31 and 60 years. 20 patients with HCC were enrolled in Group III, aged from 31 to 65. 10 normal subjects were included in the study as control group, aged 31-60 years. There was no significant difference as regard to the age and sex between the different groups (Table 1 for complete demographic and laboratory data). There was no significant deference between the 3 studied groups regarding the viral load level (Table 2).

Regarding other laboratory findings, hemoglobin concentration and platelet count were significantly higher in the control group than in patients in other studied groups, and in noncirrhotic patients than cirrhotic ones. They were significantly low in HCC group. However, the difference detected between studied groups regarding white blood cell count was not significant; in spite of the fact that IL-1 $\alpha$ affects neutrophils. This can be explained due to the total leucocytic count only being measured, which might be affected in chronic hepatitis and development of cirrhosis or HCC. All groups showed significant statistical difference as regard to liver function tests. Serum bilirubin and INR were higher in Group I (Table 1). However, liver enzymes were higher in Group III. Serum albumin was also lower in Group III.

Serum IL- $1 \alpha$ level was significantly higher in group $\mathrm{HCC}$ than in group chronic $\mathrm{HCV}$ with cirrhosis. Also, it was higher in group chronic $\mathrm{HCV}$ with cirrhosis compared to chronic $\mathrm{HCV}$ without cirrhosis group. Also, it was higher in all groups compared to the control group (Table 3, Figure 1).

There was positive significant correlation between serum IL-1 $\alpha$ and bilirubin $(P \leq 0.001)$, ALT $(P=0.006)$, AST $(P=0.001)$, and viral load $(P=0.001)$, but there was negative significant correlation between this and albumin $\left(P<0.001^{*}\right)$, $\mathrm{Hb}(P \leq 0.001)$, and white blood cells. Also, there was no significant correlation with other parameters (age, INR, urea, creatinine, platelet) as shown in Table 4. 
Table I Demographic and laboratory data of the studied groups

\begin{tabular}{|c|c|c|c|c|c|c|}
\hline \multirow[t]{2}{*}{ Characteristic } & Group I & Group II & Group III & Group IV & \multirow{2}{*}{\multicolumn{2}{|c|}{$\begin{array}{l}P \text {-value (Fisher's } \\
\text { exact test) }\end{array}$}} \\
\hline & \multicolumn{4}{|c|}{ Demographic data (n [\%]) } & & \\
\hline \multicolumn{5}{|l|}{ Age (years) } & \multicolumn{2}{|l|}{0.799} \\
\hline $31-45$ & $4(20)$ & $6(30)$ & $5(25)$ & $4(20)$ & & \\
\hline $46-55$ & $11(55)$ & $10(50)$ & $7(35)$ & $4(20)$ & & \\
\hline $56-65$ & $5(25)$ & $4(20)$ & $8(40)$ & $2(20)$ & & \\
\hline \multicolumn{5}{|l|}{ Gender } & \multicolumn{2}{|l|}{0.073} \\
\hline Male & $6(30)$ & $14(70)$ & II (55) & $4(20)$ & & \\
\hline \multirow[t]{2}{*}{ Female } & $14(70)$ & $6(30)$ & $9(45)$ & $6(30)$ & & \\
\hline & \multicolumn{4}{|c|}{ Laboratory data (mean + SD) } & $\boldsymbol{F}$ & $P$-value \\
\hline $\mathrm{Hb}(\mathrm{gm} / \mathrm{dL})$ & $9.825 \pm 1.420$ & $12.740 \pm 1.456$ & $10.005 \pm 1.121$ & $13.150 \pm 1.684$ & 26.097 & $<0.00 I^{*}$ \\
\hline WBCs $/ \mathrm{mm}^{3}$ & $5.420 \pm 2.344$ & $5.650 \pm 1.398$ & $5.285 \pm 1.472$ & $6.650 \pm 1.248$ & 1.529 & 0.0215 \\
\hline Platelet $/ \mathrm{mm}^{3}$ & $146.650 \pm 89.54$ & $110.7 \pm 24.37$ & $118.75 \pm 89.54$ & $335 \pm 88.35$ & 30.991 & $<0.00 I^{*}$ \\
\hline ALT (IU/L) & $55.6 \pm 58.504$ & $25 \pm 2.819$ & $67.2 \pm 65.755$ & $17.00 \pm 3.399$ & 4.11 & $0.01 *$ \\
\hline AST (IU/L) & $77.1 \pm 59.531$ & $27.1 \pm 2.827$ & $\mathrm{I}|0.55 \pm \mathrm{I}| 2.96$ & $22.4 \pm 3.169$ & 6.478 & $0.00 I^{*}$ \\
\hline Bilirubin (mg/dL) & $3.485 \pm 3.093$ & $0.785 \pm 0.452$ & $2.995 \pm 1.334$ & $0.69 \pm 0.088$ & 10.87 & $<0.00 I^{*}$ \\
\hline Albumin $(\mathrm{g} / \mathrm{dL})$ & $3.485 \pm 3.093$ & $3.485 \pm 3.093$ & $3.485 \pm 3.093$ & $3.485 \pm 3.093$ & 37.332 & $<0.00 I^{*}$ \\
\hline INR & $1.526 \pm 0.4 \mathrm{II}$ & I. $367 \pm 0.257$ & $1.507 \pm 0.36$ & $1.133 \pm 0.082$ & 3.959 & $0.012^{*}$ \\
\hline
\end{tabular}

Note: Group I included 20 patients with CHC with cirrhosis; Group II included 20 patients with CHC without cirrhosis; Group III included 20 patients with CHC with $\mathrm{HCC}$; Group IV: included 10 healthy persons as control group. *Statistically significant at $p \leq 0.05$.

Abbreviations: ALT, alanine aminotransferase; AST, aspartate aminotransferase; Hb, hemoglobin; INR, international normalized ratio; WBC, white blood cell.

Table 2 Mean viral load among 4 studied groups

\begin{tabular}{llllll}
\hline Viral load (IU/mL) & Group I & Group II & Group III & Group IV \\
\hline Mean + SD & & $28,450.1+27,642.9$ & $22,120.3+2,999.9$ & $25,300.4+3,679.2$ & $28,450.1+27,642.9$ \\
One-way & F & 0.764 & & & \\
ANOVA & P-value & 0.47 I & & & \\
\hline
\end{tabular}

Note: Group I included 20 patients with CHC with cirrhosis; Group II included 20 patients with CHC without cirrhosis; Group III included 20 patients with CHC with HCC; Group IV: included 10 healthy persons as control group.

Abbreviation: ANOVA, analysis of variance.

Table 3 Serum IL- I $\alpha$ levels in the studied groups

\begin{tabular}{|c|c|c|c|c|c|c|}
\hline \multicolumn{2}{|c|}{ Serum IL-I $\alpha(\mathrm{pg} / \mathrm{mL})$} & \multicolumn{5}{|l|}{ Groups } \\
\hline & & \multirow{2}{*}{$\begin{array}{l}\text { Group I } \\
19-22\end{array}$} & \multirow{2}{*}{$\frac{\text { Group II }}{14.5-17.6}$} & \multirow{2}{*}{$\frac{\text { Group III }}{23-25.8}$} & \multicolumn{2}{|l|}{ Group IV } \\
\hline Range & & & & & $10.5-12.4$ & \\
\hline Mean \pm SD & & $20.65 \pm 0.95$ & $15.70 \pm 1.07$ & $24.3 \pm 0.87$ & $11.2 \pm 0.706$ & \\
\hline \multirow[t]{2}{*}{ ANOVA } & $F$ & 551.464 & & & & \\
\hline & $P$-value & $<0.00 I^{*}$ & & & & \\
\hline \multicolumn{7}{|c|}{ Tukey's test } \\
\hline$|\&| \mid$ & & I\&III & I\&IV & II\&III & II\&IV & III\&IV \\
\hline$<0.001 *$ & & $<0.00 I^{*}$ & $<0.00 I^{*}$ & $<0.001 *$ & $<0.00 I^{*}$ & $<0.001 *$ \\
\hline
\end{tabular}

Notes: $F$ : ANOVA, *statistically significant at $p \leq 0.05$. Group I included 20 patients with $\mathrm{CHC}$ with cirrhosis; Group II included 20 patients with $\mathrm{CHC}$ without cirrhosis; Group III included 20 patients with CHC with HCC; Group IV: included 10 healthy persons as control group.

Abbreviations: ANOVA, analysis of variance; IL-I $\alpha$, interleukin-I $\alpha$.

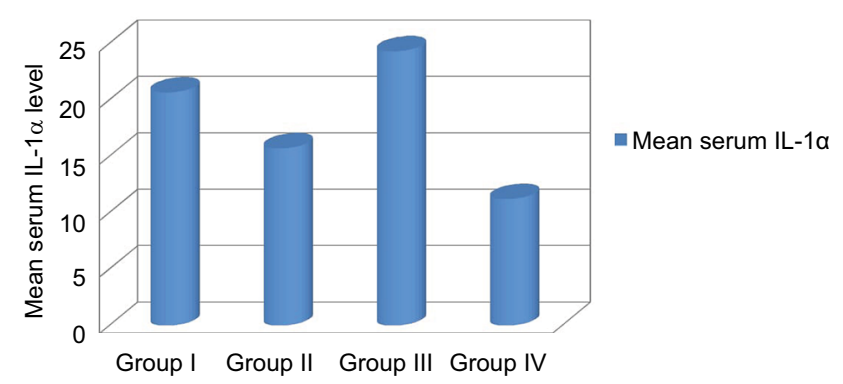

Figure I Comparison of serum IL-I $\alpha$ levels in the studied groups.

Note: Group I included 20 patients with CHC with cirrhosis; Group II included 20 patients with $\mathrm{CHC}$ without cirrhosis; Group III included 20 patients with $\mathrm{CHC}$ with HCC; Group IV: included I0 healthy persons as control group.

Abbreviation: IL-I $\alpha$, interleukin- $\mid \alpha$.

\section{Discussion}

Cytokines, as the products of host response to inflammation, play an important role in the defense against viral infections. However, in HCV infection they may play a prominent role in liver damage. ${ }^{32}$

Proinflammatory cytokines such as IL-1, TNF, and IL-8 play a role in liver injury during acute and chronic liver disease. ${ }^{22}$

In the present study, we measured serum levels of IL- $1 \alpha$. Levels were high among all groups compared to the control group. It was higher in cirrhotic cases compared to noncirrhotic ones and higher in HCC patients when compared to cases with or without cirrhosis. 
Table 4 Correlation between serum IL-I $\alpha$ with different parameters in patients in the various groups

\begin{tabular}{|c|c|c|}
\hline & \multicolumn{2}{|c|}{ Serum IL-I $\alpha(\mathrm{pg} / \mathrm{mL})$} \\
\hline & $r$ & $P$-value \\
\hline Age & 0.135 & $0.302(>0.05)$ \\
\hline Bilirubin (mg/dL) & 0.453 & $<0.001 *(<0.05)$ \\
\hline Albumin (g/dL) & -0.658 & $<0.001 *(<0.05)$ \\
\hline INR & 0.135 & $0.303(>0.05)$ \\
\hline ALT (IU/L) & 0.349 & $0.006 *(<0.05)$ \\
\hline AST (IU/L) & 0.428 & $0.001 *(<0.05)$ \\
\hline Urea & 0.130 & $0.610(>0.05)$ \\
\hline Creatinine & 0.100 & $0.060(>0.05)$ \\
\hline $\mathrm{HB}(\mathrm{g} / \mathrm{dL})$ & -0.600 & $<0.001 *(<0.05)$ \\
\hline WBCs & -0.101 & $0.443(>0.05)$ \\
\hline Platelet & 0.083 & $0.530(>0.05)$ \\
\hline Viral load (IU/mL) & 0.424 & $0.001 *(<0.05)$ \\
\hline
\end{tabular}

Notes: Correlations, $r$ : Pearson coefficient, *statistically significant at $p \leq 0.05$.

Abbreviations: ALT, alanine aminotransferase; AST, aspartate aminotransferase; $\mathrm{Hb}$, hemoglobin; IL-I $\alpha$, interleukin-I $\alpha$; INR, international normalized ratio; WBC, white blood cell.

This is in agreement with Lecube et al's $\mathrm{s}^{33}$ study which showed that all the proinflammatory cytokines were significantly higher in anti-HCV+ cirrhotic patients than in anti$\mathrm{HCV}$ - cirrhotic cases. ${ }^{33}$

In Wang et al's ${ }^{34}$ study, the proinflammatory cytokines, the IL-1 family (IL-1 and IL-1ra), and TNF were studied in 274 Japanese patients with chronic HCV infection and 55 healthy individuals using standard polymerase chain reaction-based genotyping techniques. There was elevation in cytokine levels in the chronic HCV group. ${ }^{34}$

Elevation of cytokine level in chronic HCV patients was also found in the study done by Vanis et al, ${ }^{35}$ who found that IL-1 $\alpha$ had the highest mean concentration in the group with viral hepatitis $\mathrm{C}$, with PCR-positive test, and then in chronic viral hepatitis $\mathrm{C}$ with PCR-negative test than IL-1 $\alpha$ in the healthy group. This may be explained by the fact that IL- $1 \alpha$ has an important role as a marker of both inflammation and hepatic injury, particularly in the course of hepatitis $\mathrm{C}$.

The present study agrees also with Huang et al's results ${ }^{36}$ which found that cytokines (IL1, IL 2r IL-6, and TNF- $\alpha$ ) levels were significantly elevated in $\mathrm{CHC}$ with cirrhosis, $\mathrm{CHC}$, and HCC compared with controls. These levels reflect hepatic dysfunction better than liver inflammation parameters, which might explain the higher serum concentrations of cytokines in cirrhosis.

Budhu and Wang ${ }^{37}$ study showed elevation of the serum levels of proinflammatory cytokines in HCC patients.

Lin et $a l^{38}$ stated that IL- $1 \alpha$ is one of the most important inflammatory cytokines involved in inflammation and tumor development. However, the role of membrane IL- $1 \alpha$ in HCC tumorigenesis is still not clear. They found that membrane IL- $1 \alpha$ potently inhibited HCC tumor growth. Further in vitro studies demonstrated that membrane IL- $1 \alpha$ could directly activate T-cells and NK cells in a cell contact-dependent manner. Their studies demonstrated that membrane IL- $1 \alpha$ could promote antitumor immune responses through activation of T- and NK cells. ${ }^{38}$

Correlation of IL-1 $\alpha$ with various parameters of the study showed a positive association with serum bilirubin, ALT, and viral load. There was a significant negative correlation with albumin and hemoglobin. The increase in ALT and bilirubin reflects hepatic inflammation, which gets worse with progress of $\mathrm{HCV}$.

It is well known that IL- $1 \alpha$ level mirrors inflammatory process in the liver. Olteanu et $\mathrm{al}^{39}$ found that selective deficiency of IL-1 $\alpha$ in Kupffer cells reduces liver inflammation and expression of inflammatory cytokines, which may implicate Kupffer cell-derived IL- $1 \alpha$ in steatohepatitis development. Other IL-1 family ligands are critical for the development of diverse diseases, including inflammatory and allergic diseases. ${ }^{39}$ Tseilikman et a ${ }^{40}$ found that IL-1 $\beta$ treatment causes liver inflammation, consisting of infiltrating monocytes and the appearance of necrosis by increasing lipid peroxidation and protein carbonylation. Blocking IL-1 receptors with an antagonist significantly rescues stress-induced liver injury, suggesting that IL-1 might be involved in the cascade of liver injury initiated by sustained stress. There was a significant negative correlation with albumin which reflects the synthetic function of the liver. However, we failed to find a significant correlation between IL- $1 \alpha$ and INR. ${ }^{40}$ However, we failed to find a significant correlation between IL-1 $\alpha$ and INR.

Correlation of IL- $1 \alpha$ with viral load agrees with the results of Vanis et al, ${ }^{35}$ who found that analysis of serum level of IL- $1 \alpha$ showed a high degree of correlation with active replication of genetic material (HCV-RNA PCR positive).

The limitations of this study were the small number of patients and the dependence on laboratory data and radiological criteria for diagnosis of cirrhosis and HCC rather than liver biopsy in many patients. IL- $1 \beta$ and TGF- $\beta$ were not evaluated here. However, it can be said that IL- $1 \beta$ may decrease in CHC, and TGF- $\beta$ is responsible mainly for fibrogenesis. This study also included an HCC group. The cost is also a limitation here. Another limitation was that the study was directed toward presence of cirrhosis or HCC without focusing on the stage of HCC or presence or absence of hepatic decompensation. 


\section{Conclusion}

The serum level of IL- $1 \alpha$ is elevated in patients with CHC. In addition, the levels correlate well with deterioration of liver function in chronic HCV patients, and also with the development of HCC. It can be considered as a promising parameter of inflammatory activity and fibrosis evaluation in chronic liver disease.

\section{Disclosure}

The authors report no conflicts of interest in this work.

\section{References}

1. Zaltron S, Spinetti A, Biasi L, Baiguera C, Castelli F. Chronic HCV infection: epidemiological and clinical relevance. BMC Infect Dis. 2012;12(Suppl 2):S2.

2. Perz JF, Armstrong GL, Farrington LA, Hutin YJ, Bell BP. The contributions of hepatitis $\mathrm{B}$ virus and hepatitis $\mathrm{C}$ virus to cirrhosis and primary liver cancer worldwide. J Hepatol. 2006;45(4):529-538.

3. Thomas E, Ghany MG, Liang TJ. The application and mechanism of action of ribavirin in therapy of hepatitis C. Antivir Chem Chemother. 2013;23(1):1-12.

4. Mohamoud YA, Mumtaz GR, Riome S, Miller D, Abu-Raddad LJ. The epidemiology of hepatitis C virus in Egypt: a systematic review and data synthesis. BMC Infect Dis. 2013;13:288.

5. Elwan N, Elfert A, Abd-Elsalam S, et al. Study of hepatic steatosis index in patients with chronic HCV infection. Int J Curr Microbiol App Sci. 2016;5(5):266-274.

6. Abd-Elsalam S, Sharaf-Eldin M, Soliman S, Elfert A, Badawi R, Ahmad YK. Efficacy and safety of sofosbuvir plus ribavirin for treatment of cirrhotic patients with genotype 4 hepatitis $C$ virus in real-life clinical practice. Arch Virol. 2018;163(1):51-56.

7. Ahmed OA, Kaisar HH, Hawash N, et al. Efficacy of sofosbuvir plus ribavirin with or without peginterferon-alfa in treatment of a cohort of Egyptian patients with hepatitis C virus infection. Infect Disord Drug Targets. 2017;17(2):95-100.

8. Ahmed OA, Elsebaey MA, Fouad MHA, et al. Outcomes and predictors of treatment response with sofosbuvir plus daclatasvir with or without ribavirin in Egyptian patients with genotype 4 hepatitis $C$ virus infection. Infect Drug Resist. 2018;11:441-445.

9. Ahmed OA, Kaisar HH, Badawi R, et al. Efficacy and safety of sofosbuvir-ledipasvir for treatment of a cohort of Egyptian patients with chronic hepatitis C genotype 4 infection. Infect Drug Resist. 2018;11:295-298.

10. Bataller R, Brenner DA. Liver fibrosis. J Clin Invest. 2005;115(2):209-218.

11. Galambos JT. Alcoholic liver disease, fatty liver and cirrhosis. In: Berk JE, Haubrich WS, Kalser MH, Roth JLA, Schaffner F, editors. Bockus Gastroenterology. 4th ed. Philadelphia: WB Saunders; 1985:2985-3048.

12. Tsochatzis EA, Germani G, Burroughs AK. Transarterial chemoembolization, transarterial chemotherapy, and intra-arterial chemotherapy for hepatocellular carcinoma treatment. Semin Oncol. 2010;37(2):89-93.

13. Ferlay J, Shin HR, Bray F, Forman D, Mathers C, Parkin DM. Estimates of worldwide burden of cancer in 2008: GLOBOCAN 2008. Int $J$ Cancer. 2010;127(12):2893-2917.

14. Ziada DH, El Sadany S, Soliman H, et al. Prevalence of hepatocellular carcinoma in chronic hepatitis C patients in Mid Delta, Egypt: a single center study. J Egypt Natl Canc Inst. 2016;28(4):257-262.

15. Sheta E, El-Kalla F, El-Gharib M, et al. Comparison of single-session transarterial chemoembolization combined with microwave ablation or radiofrequency ablation in the treatment of hepatocellular carcinoma: a randomized-controlled study. Eur J Gastroenterol Hepatol. 2016;28(10):1198-1203.
16. Spengler U, Lechmann M, Irrgang B, Dumoulin FL, Sauerbruch T. Immune responses in hepatitis $\mathrm{C}$ virus infection. $J$ Hepatol. 1996;24(Suppl 2):20-25.

17. Lechmann M, Ihlenfeld HG, Braunschweiger I, et al. T and B cell responses to different hepatitis $\mathrm{C}$ virus antigens in patients with chronic hepatitis C infection and healthy seropositives. Hepatology. 1996;24(4):790-795.

18. Thimmte R, Oldach D, Chang KM, Steiger C, Ray SC, Chisari FV. Determinants of viral clearance and persistence during acute hepatitis C virus infection. J Exp Med. 2001;194(10):1395-1406.

19. McClain CJ, Barve S, Deaciuc I, Kugelmas M, Hill D. Cytokines in alcoholic liver disease. Semin Liver Dis. 1999;19(2):205-219.

20. Falasca K, Ucciferri C, Dalessandro M, et al. Cytokine patterns correlate with liver damage in patients with chronic hepatitis B and C. Ann Clin Lab Sci. 2006;36(2):144-150.

21. Schmidt J, Blum HE, Thimme R. T-cell responses in hepatitis B and $\mathrm{C}$ virus infection: similarities and differences. Emerg Microbes Infect. 2013;2(3):e15.

22. Dinarello CA. Proinflammatory cytokines. Chest. 2000;118(2):503-508.

23. Dumoulin FL, Leifeld L, Honecker U, Sauerbruch T, Spengler U. Intrahepatic expression of interleukin-1 beta and tumor necrosis factor alpha in chronic hepatitis C. J Infect Dis. 1999;180(5):1704-1708.

24. Kaplanski G, Farnarier C, Payan MJ, Bongrand P, Durand JM. Increased levels of soluble adhesion molecules in the serum of patients with hepatitis C. Correlation with cytokine concentrations and liver inflammation and fibrosis. Dig Dis Sci. 1997;42(11):2277-2284.

25. Ichikawa T, Nakao K, Nakata K, et al. Involvement of IL-1 $\beta$ and IL-10 in IFN- $\alpha$-mediated antiviral gene induction in human hepatoma cells. Biochem Biophys Res Commun. 2002;294(2):414-422.

26. Brody DT, Durum SK. Membrane IL-1: IL-1 alpha precursor binds to the plasma membrane via a lectin-like interaction. J Immunol. 1989;143(4):1183-1187.

27. Kurt-Jones EA, Beller DI, Mizel SB, Unanue ER. Identification of a membrane -associated interleukin 1 in macrophages. Proc Natl Acad Sci U S A. 1985;82(4):1204-1208.

28. Lin D, Lei L, Liu Y, et al. Membrane IL1 $\alpha$ inhibits the development of hepatocellular carcinoma via promoting T- and NK-cell activation. Cancer Res. 2016;76(11):3179-3188.

29. Kasprzak A, Zabel Z, Biczysko W, et al. Expression of cytokines (TNF$\alpha$, IL-1 $\alpha$, and IL-2) in chronic hepatitis C: comparative hybridocytochemical and immunocytochemical study in children and adult patients. J Histochem Cytochem. 2004;52(1):29-38.

30. Yu AS, Keeffe EB. Management of hepatocellular carcinoma. Rev Gastroenterol Disord. 2003;3(1):9-24.

31. Murakami T, Kim T, Takahashi S, Nakamura H. Hepatocellular carcinoma multidetector row helical CT. Abdom Imaging. 2002;27(2):139-146.

32. Koziel MJ. Cytokines in viral hepatitis C. Semin Liver Dis. 1999; 19(2):157-169.

33. Lecube A, Hernández C, Genescà J, Simó R. Proinflammatory cytokines, insulin resistance, and insulin secretion in chronic hepatitis $\mathrm{C}$ patients. Diabetes Care. 2006;29(5):1096-1101.

34. Wang Y, Kato N, Hoshida Y, et al. Interleukin-1 $\beta$ gene polymorphisms associated with hepatocellular carcinoma in hepatitis Cvirus infection. Hepatology. 2003;37(1):65-71.

35. Vanis N, Mehmedovic A, Mesihovic R. Use of serum levels of proinflammatory cytokine IL- $1 \alpha$ in chronic hepatitis C. Coll Antropol. 2015;39(1):75-79.

36. Huang YS, Hwang SJ, Chan CY, et al. Serum levels of cytokines in hepatitis C-related liver disease. Zhonghua Yi Xue Za Zhi (Taipei). 1999;62(6):327-333.

37. Budhu A, Wang XW. The role of cytokines in hepatocellular carcinoma. J Leukoc Biol. 2006;80(6):1197-1213.

38. Lin D, Lei L, Liu Y, et al. Membrane IL-1 $\alpha$ inhibits the development of hepatocellular carcinoma via promoting $\mathrm{T}$ and NK cell activation. Cancer Res. 2016;76(11):3179-3188. 
39. Olteanu S, Kandel-Kfir M, Shaish A, et al. Lack of interleukin-1 $\alpha$ in Kupffer cells attenuates liver inflammation and expression of inflammatory cytokines in hypercholesterolaemic mice. Dig Liver Dis. 2014;46(5):433-439.
40. Tseilikman V, Kozochkin D, Synitsky A, et al. Does stress-induced release of interleukin-1 cause liver injury? Cell Mol Neurobiol. 2012;32(7):1069-1078.

\section{Publish your work in this journal}

The Journal of Inflammation Research is an international, peer-reviewed open access journal that welcomes laboratory and clinical findings on the molecular basis, cell biology and pharmacology of inflammation including original research, reviews, symposium reports, hypothesis formation and commentaries on: acute/chronic inflammation; mediators of

\section{Dovepress}

inflammation; cellular processes; molecular mechanisms; pharmacology and novel anti-inflammatory drugs; clinical conditions involving inflammation. The manuscript management system is completely online and includes a very quick and fair peer-review system. Visit http://www.dove press.com/testimonials.php to read real quotes from published authors.

Submit your manuscript here: https://www.dovepress.com/journal-of-inflammation-research-journal 